\title{
Structural Modification of the Black Bengal Buck (Capra hircus) Acrosome During Post-testicular Maturation of Spermatozoa
}

\author{
Modificación Estructural del Acrosoma de la Cabra Black Bengal \\ (Capra hircus) Durante la Maduración de los Espermatozoides
}

Uttam Datta*; Soumendra Kumar Bandopadhyay $^{* *}$ \& Manik Lal Hembram****

DATTA, U.; BANDOPADHYAY, S. K. \& HEMBRAM, M. L. Structural modification of the black bengal buck (Capra hircus) acrosome during post-testicular maturation of spermatozoa. Int. J. Morphol., 32(4):1502-1508, 2014.

SUMMARY: The present study was conducted to measure various biometric parameters of intact/normal acrosomes (AC) collected respectively from caput, corpus and cauda epididymis and vas deferens of Black Bengal buck. Giemsa stained acrosomes were measured after camera lucida drawings. Observations revealed dimensional characters of the acrosomal cap diminished gradually and significantly $(\mathrm{p}<0.01, \mathrm{p}<0.05)$ during spermatozoa maturation phases in the different regions of the excurrent duct. Shape and size of the $\mathrm{AC}$ were also found to be influenced significantly $(\mathrm{p}<0.01, \mathrm{p}<0.05)$ by the age and body weight of the animals. The structural modification along with decrease in the morphology of the AC reflected one of the maturational indexes of the male gametes in Black Bengal buck.

KEY WORDS: Black Bengal buck; Epididymis; Acrosome; Biometry.

\section{INTRODUCTION}

During propagation of the sperm cells through different regions of the male reproductive tract, various physical and chemical alterations in the sperm plasma membrane (SPM) including its lipid and protein contents (Yanagimachi, 1994) as well as sperm structural components undergo changes (Bearer \& Friend, 1990). These changes enable spermatozoa to fertilize egg (Glover, 1974; Katz et al., 1989). One of the important changes in the spermatozoon morphology during maturation phases is structural modifications of the $\mathrm{AC}$ that alters the shape and size of the sperm head (Fawcett \& Hollenberg, 1963; Guraya, 1987; Hafez, 1987). Ultrastructural investigations revealed that the appearance and topographical configuration of the SPM are altered during epididymal transit (Bedford, 1965; Bedford $\&$ Nicander, 1971). These alterations typically involve in reduction in size and a change in the apical segments, change in the appearance of acrosomal contents (Olson et al., 2003), and change in the density and distribution of the membrane particles (Lopez et al., 2007). However, Sperm morphology in combination with other objective traits is useful to determine the fertility index of an individual. Abnormal bull sperm morphology has been found correlated with reduced fertility (Sekoni \& Gustafsson, 1987; Correa et al., 1997). In particular, the occurrence of abnormal sperm head morphology is associated with lower fertility in bull (Saacke \& White, 1972; Sekoni \& Gustafsson). Therefore, evaluation of spermatozoan morphology provides information on testicular function and fertility potential of a male (Melrose, 1962; Hann et al., 1969). Moreover, it has been reported that age and body weight of an individual also influence the dimensional characters of the ejaculated spermatozoa (Beatty, 1969; Pangawkar \& Mittal, 1978; Bandopadhyay, 1981).

Hence, present study on the morphological changes of $\mathrm{AC}$ and their probable relationship with the age and body weight of the animal during spermatozoan maturation phases

\footnotetext{
Lecturer, Department of Veterinary Gynecology \& Obstetrics, Faculty of Veterinary and Animal Science, West Bengal University of Animal and Fishery Sciences, West Bengal, India.

** Former Professor, Department of Veterinary Gynecology \& Obstetrics, Faculty of Veterinary and Animal Science, West Bengal University of Animal and Fishery Sciences, West Bengal, India.

*** Ph.D. Scholar, Department of Veterinary Gynecology \& Obstetrics, Faculty of Veterinary and Animal Science, West Bengal University of Animal and Fishery Sciences, West Bengal, India.
} 
was undertaken to investigate the nature of changeable morphometric characteristics of the AC in the different regions of male reproductive tract in Black Bengal buck.

\section{MATERIAL AND METHOD}

Forty-five adult and healthy Black Bengal bucks were selected from goat breeding farm of the University. The animals were divided into two age groups (Group I - 3 years; Group II - above 3 to $31 / 2$ years), and three weight groups (Group 1= $12.5 \mathrm{~kg}$; Group 2= 12.5 to $13.5 \mathrm{~kg}$ and Group 3= 13.5 to $14.5 \mathrm{~kg}$ ) respectively. All the animals were maintained on the standard balanced feed and water was supplied ad libitum.

For the experiment, each buck was castrated by open method (O'Conner, 1980). Immediately after castration, tunica albuginea were removed from both the testis. Ligatures were placed unilaterally as per anatomical positions at the proximal end of the vas deferens and cauda epididymis separately, and distal to the caput epididymis, vas efferentia and vas deferens respectively. After ligations, epididymides including vas deferenses were dissected out from the testes. Each ligated region (caput, corpus, cauda and vas deferens) was cut again and minced separately into $2 \mathrm{ml}$ of $0.15 \mathrm{M}$ phosphate buffer saline (PBS), pH 7.4 at $37^{\circ} \mathrm{C}$ into different polystyrene Petri dishes. Luminal content from each portion was collected separately by giving gentle pressure on the excised tissues into the medium with individual clean glass rods. The resultant suspensions were filtered through separate nitex membrane (150 ?m pore size) to free the cellular debris. Each filtrate was collected into individual glass test tubes, centrifuged at $500 \mathrm{~g}$ for $10 \mathrm{~min}$ and the supernatants were discarded. Finally, $200 \mu \mathrm{l}$ of $0.15 \mathrm{M}$ PBS was added to each sperm pellet separately, vortexed for $3 \mathrm{~s}$ and kept at $37^{\circ} \mathrm{C}$ into an incubator provided with $5 \% \mathrm{CO}_{2}$ in air for 15 min allowing sperm cells to swim up into the medium. After incubation, sperm cells from upper layer of the mediums were aspirated carefully by micropipettes and transferred into individual coded test tubes. Subjective evaluation (WHO, 1987) of the spermatozoan motility (0-5 scale) from each region was performed under the Leitz phase contrast microscope (x100; x200). Spermatozoan motility $>40 \%$ were considered for the experiment. However, as the spermatozoa from the caput region are immotile we considered the whole sperm suspension for the experiment.

Acrosome morphology was assessed using Giemsa staining method (Harayama, 2003; Harayama et al., 2004) with some modifications. Uniform smears were drawn on the coded microscopic glass slides (pretreated with $70 \%$ al- cohol) with $10 \mu \mathrm{l}$ of sperm suspension prepared from both sides of the different regions of the excurrent duct. The smears were air dried at $37^{\circ} \mathrm{C}$ on a hot plate and fixed for 15 $\mathrm{min}$ in methanol. Fixed smears were stained for $15 \mathrm{~min}$ with $6 \%$ potassium dichromate dissolved in $0.01 \%$ of aniline blue solution prepared in PBS, pH 6.8. Finally, smears were restained in Giemsa solution ( $0.15 \mathrm{~g}$ of Giemsa dye dissolved in $100 \mathrm{ml}$ of PBS, $\mathrm{pH} \mathrm{6.8)}$ for $1 \mathrm{~h}$ at room temperature in humid condition. All the stained smears were washed with a gentle flow of $0.15 \mathrm{M}$ PBS for 2 min followed by a single dip into distilled water. Washed smears were treated with clove oil for $15 \mathrm{sec}$, dehydrated in a xylene bath for $1 \mathrm{~min}$ and mounted with DPX.

Ten normal stained sperm cells with normal and intact AC from each coded slides were drawn by Camera Lucida $(x 7,700)$ and measured (Pant \& Mukherjee, 1973). Following dimensional characters (Fig. 1) were determined (Pant \& Mukherjee, 1973; Ostermeier et al., 2001) for the acrosomal length (al) [the distance between the midpoint of the base line of the $\mathrm{AC}$ and its apex, i.e. $\mathrm{AB}$ ]; acrosomal breadth (ab) [maximum scale reading of the line parallel to the base line, i.e. $\mathrm{CD}$ ]; acrosomal breadth at base (abb) [maximum scale reading of a line of the acrosomal base, i.e. EF]; acrosomal shape (as) [the ratio of the length and breadth of the cap, i.e. $\mathrm{AB} / \mathrm{CD}$ ] and acrosomal area (aa) which was measured by a planimeter from the Camera Lucida drawings. All the mensuration characters were expressed as $\mu^{2}$ and $\mu \mathrm{m}$. The mean percentage data were transformed to arcsin value and analyzed statistically (Snedecor \& Cochran, 1980).

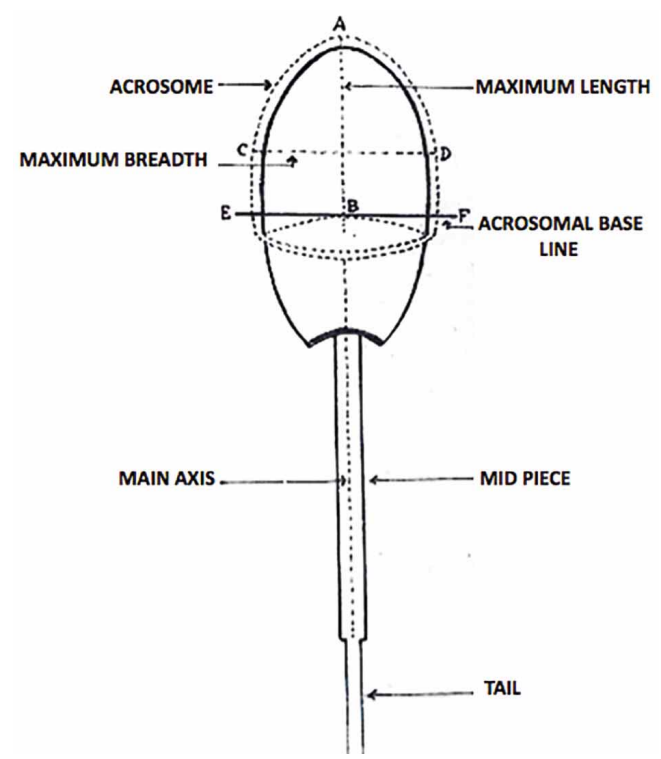

Fig. 1 Diagrammatic presentation (Camera Lucida drawing) of different dimensional characters of acrosomal cap. ("al"acrosomal length $[\mathrm{AB}]$; "ab"-acrosomal breadth [CD]; "abb"acrosomal breadth at base $[\mathrm{EF}]$; "as"-acrosomal shape $[\mathrm{AB} /$ $\mathrm{CD}])$ 


\section{RESULTS}

The modified Giemsa staining method produced a clear and prominent view for the caprine acrosomal cap (Fig. 2) under the microscope.

Table I depicts the different dimensional characters of the $\mathrm{AC}$ from the experimental regions. Highly significant variations $(\mathrm{p}<0.01)$ in all the measured dimensional characters were found between the regions. But in "al" between cauda vs. corpus; and in "aa" between cauda vs. vas deferens only significant variation $(\mathrm{p}<0.05)$ were found. However, in "al", "ab", "abb" and in "as" the variations between cauda and vas deferens were non significant (Table II). Statistical analysis also indicated that all the dimensional characters of the AC diminished significantly during spermatozoan journey from caput to vas deferens. The relationship (Table III) of each dimensional characters of AC

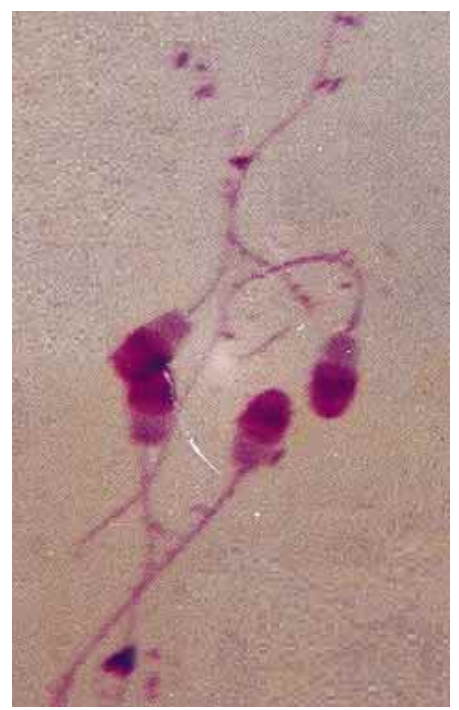

Fig. 2. Micrograph of Black Bengal buck sperm showing acrosomal caps (Modified Giemsa, x 1000) among different regions of the excurrent duct exhibited higher significance $(\mathrm{p}<0.01)$, than "al" in between cauda vs. vas deferens $(\mathrm{p}<0.05)$. For "abb" no such relationship was existed in between corpus vs. cauda.

Least square analysis of variance and Duncan's Multiple Range tests (DMR test) were performed to find out whether individual's age and body weight had any influence on the mensuration characters of $\mathrm{AC}$ among the different regions. Analysis revealed that due to variation / effect of age, dimensional characters like "ab" in caput, corpus, cauda and vas deferens; "abb" in cauda and vas deferens and "as" in caput in age group I ( 3 yrs) varied significantly $(\mathrm{p}<0.01)$ than age group II (above 3 yrs). Moreover, DMR test indicated that two age groups exhibited significant variations $(\mathrm{p}<0.01)$ due to effect of age only in "ab" among the four experimental regions, "abb" in the caudal region and in the vas deferens, and "as" in the caput epididymis (Table IV) respectively.

Morphometric characters of the $\mathrm{AC}$ were also found to be influenced by the body weight of the animals significantly $(p<0.01)$ in all the four regions on the "ab"; "abb" ( $p<0.01)$ only in the cauda and vas deferens, and "as" $(\mathrm{p}<0.05)$ in the caput region only. DMR test also revealed that weight group 1 varied significantly $(\mathrm{p}<0.01)$ from weight group 2 and 3, whereas latter two groups did not exhibit any variation in "ab" from caput, corpus and in vas deferens, and "abb" in cauda and vas deferens respectively. However, "as" in caput and

Table I. Morphometric characteristics of the acrosomal cap from different epididymal regions and vasdeferens of Black Bengal buck.

\begin{tabular}{lccccc}
\hline \multirow{2}{*}{ Region } & $\begin{array}{c}\text { Length } \\
(\mu)\end{array}$ & $\begin{array}{c}\text { Breadth } \\
(\mu)\end{array}$ & $\begin{array}{c}\text { Breadth at base } \\
(\mu)\end{array}$ & $\begin{array}{c}\text { Area } \\
\left(\mu^{2}\right)\end{array}$ & Shape \\
\hline Caput & $4.24 \pm 0.005$ & $4.33 \pm 0.01$ & $4.16 \pm 0.01$ & $16.33 \pm 0.1$ & $1.27 \pm 0.004$ \\
Corpus & $4.17 \pm 0.008$ & $4.23 \pm 0.01$ & $4.08 \pm 0.01$ & $15.36 \pm 0.09$ & $1.27 \pm 0.005$ \\
Cauda & $4.11 \pm 0.02$ & $4.09 \pm 0.01$ & $3.99 \pm 0.01$ & $14.18 \pm 0.11$ & $1.29 \pm 0.005$ \\
Vas deferens & $4.08 \pm 0.007$ & $4.08 \pm 0.01$ & $3.99 \pm 0.01$ & $14.17 \pm 0.11$ & $1.29 \pm 0.006$ \\
\hline
\end{tabular}

$\mathrm{n}=45$; Values are expressed as mean \pm SE.

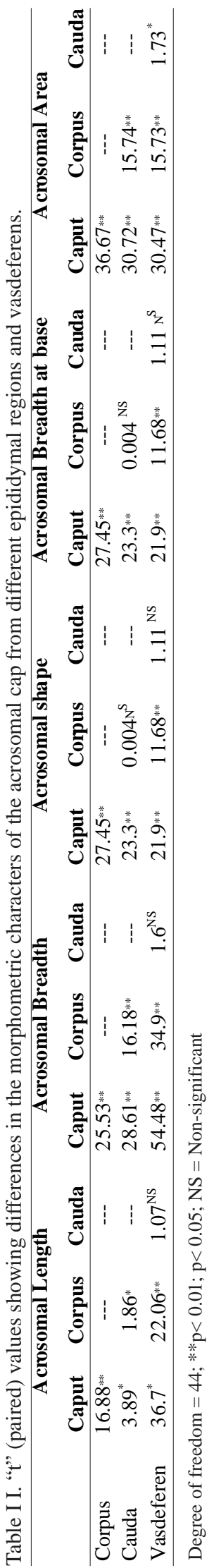




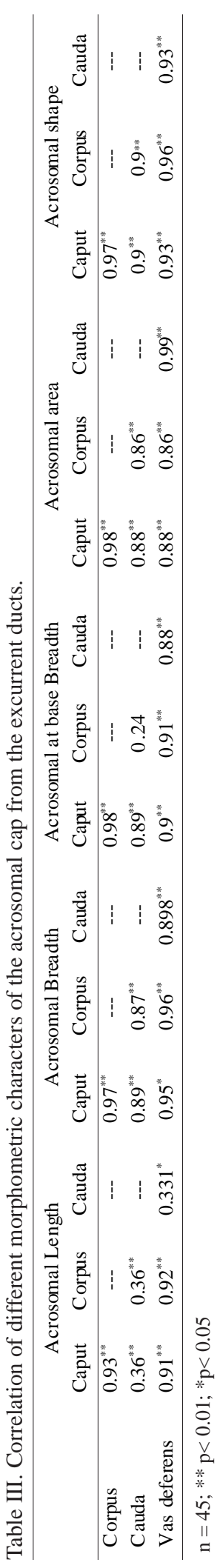

"ab" in cauda, where three weight groups varied significantly $(\mathrm{p}<0.01)$ from each other (Table $\mathrm{V})$.

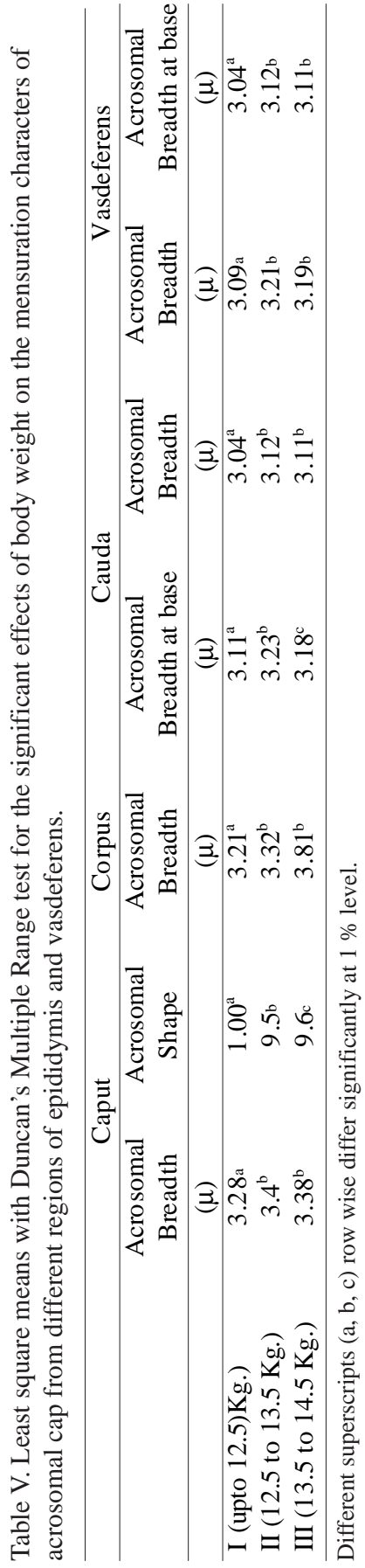

\section{DISCUSSION}

Sperm maturation in the epididymis is a gradual process that results in a number of successive changes in the spermatozoa. These successive changes alter the morphology of the spermatozoon, so that their properties and functions are also modified while they move along the excurrent ducts (Briz et al., 1995). Some of the distinctive structural changes during spermatozoal maturation are condensation of acrosome (Fawcett \& Hollenberg; Bedford, 1964; Bedford \& Nicander; Paüfler \& Foote, 1968; Hamilton, 1972; Jones et al., 1974; Jones, 1975; Hanks, 1977), reduction in the acrosomal size (Bedford, 1965) as well as loss of the acrosomal components (Holt, 1980). Significant decreases in the dimensional characters of the AC from the epididymal segments in the Black Bengal buck are also consistent with the above findings. Present observation also revealed that AC in the caput sperm had the greatest surface area than the spermatozoa from cauda and vas deferens. Compaction of the nucleus and acrosomal material are related for the decrease of the surface area. These observations also simulate with the findings of Fornés \& de Rosas (1989) in rat. Moreover, higher osmotic pressure of the epididymal secretion than that of blood (Lindhal \& Kihlström, 1952; Glover; Guraya) is also responsible for dehydration of the sperm cells resulting decrease in the permeability of water content of the acrosome (Hamilton; 
Salisbury et al., 1978). Thus through progressive loss of water and a corresponding increase in the specific gravity (Lavon et al., 1966; Salisbury et al.), swollen acrosomal membrane in caput gradually decreases in their shape and size during their transit (Hamilton; Jones et al.; Hanks) resulting adherence of AC to the sperm nucleus (Jones, 1971, 1975).

Present experiment also revealed that acrosomal area (aa) reduces further in the vas deferens, the reason might be that acrosome undergoes further dehydration in this region as reported in human (Hinrichsen \& Blaquier, 1980) and in rat (Brotherton, 1976).

Statistical analysis also revealed age and body weight of the animal influenced the dimensional characters of the maturing $\mathrm{AC}$ in the excurrent duct. The causal factor(s) of this type of influence in adult animals of close age groups is / are not known clearly. So far reviewed, reports on the influence of age and body weight of the individual on the morphology of AC were not found, but, Beatty and Bandopadhyay reported that age and body weight of the animal had more pronounced effect on the dimensional characters of the ejaculated spermatozoa in mice and buffalo bull respectively. Pangawkar $\&$ Mittal also stated that quantitative morphological characters which depend on the strain, breed and species could be affected by age, seasons, temperature shock and by the extender. However, alterations in the biophysical and biochemical properties in the epididymal environment could be one of the causal factors in this observed variation.

The gradual diminution and/or alteration in the shape and size of the AC during their sojourn in the male reproductive tract, and the normal dimensions of the $\mathrm{AC}$ in the different regions of the reproductive tract in Black Bengal buck could be helpful in judging the epididymal environment as well as abnormal morphology of the AC.

DATTA, U.; BANDOPADHYAY, S. K. \& HEMBRAM, M. L. Modificación estructural del acrosoma de la Cabra Black Bengal (Capra hircus) durante la maduración de los espermatozoides. Int. J. Morphol., 32(4):1502-1508, 2014.

RESUMEN: El presente estudio se realizó para medir diversos parámetros biométricos del acrosoma (AC) intacto/normal recogido desde la cabeza, cuerpo y cola del epidídimo y vas deferens de la Cabra Black Bengal. Los AC teñidos con Giemsa fueron medidos después de la captura con cámara lúcida. Las observaciones revelaron caracteres dimensionales del capuchón acrosomal que disminuyeron gradualmente y de manera significativa $(\mathrm{p}<0,01, \mathrm{p}<0,05)$ durante fases de maduración espermatática en las diferentes regiones del conducto. La forma y tamaño del AC también fueron influenciados de manera significativa $(\mathrm{p}<0,01, \mathrm{p}<0,05)$ por la edad y el peso corporal de los animales. La modificación estructural junto con los cambios morfológicos del AC refleja uno de los índices de maduración de los gametos masculinos de la Cabra Black Bengal.

PALABRAS CLAVE: Cabra Black Bengal; Epidídimo; Acrosoma; Biometría.

\section{REFERENCES}

Bandopadhyay, S. K. Cytomorphological studies of buffalo spermatozoa with reference to preservation. $\mathrm{Ph} . \mathrm{D}$. Thesis. West Bengal, Bidhan Chandra Krishi Viswavidyalaya, 1981.

Bearer, E. L. \& Friend, D. S. Morphology of mammalian sperm membranes during differentiation, maturation, and capacitation. J. Electron. Microsc. Tech., 16(4):281-97, 1990.

Beatty, R. A. A genetic study of spermatozoan dimensions in mice selected for body weight. Indian J. Hered., 1:9-21, 1969.

Bedford, J. M. Changes in fine structure of the rabbit sperm head during passage through the epididymis. J. Anat., 99(Pt. 4):891-906, 1965.

Bedford, J. M. Changes in the fine structure of rabbit sperm head during passage through the epididymis. Toronto, Proceedings of the V International Congress of Animal Reproduction, 1964.
Bedford, J. M. \& Nicander, L. Ultrastructural changes in the acrosome and sperm membranes during maturation of spermatozoa in the testis and epididymis of the rabbits and monkey. J. Anat., 108(Pt. 3):527-43, 1971.

Briz, M. D.; Bonet, S.; Pinart, B.; Egozcue, J. \& Camps, R. Comparative study of boar sperm coming from the caput, corpus, and cauda regions of the epididymis. J. Androl., 16(2):175-88, 1995.

Brotherton, J. Difference in size between spermatozoa from the cauda epididymidis and the caput epididymidis of the rat. $J$. Reprod. Fertil., 48(2):365-6, 1976.

Correa, J. R.; Pace, M. M. \& Zavos, P. M. Relationships among frozen-thawed sperm characteristics assessed via the routine semen analysis, sperm functional tests and fertility of bulls in an artificial insemination program. Thereogenology, 48(5):721-31, 1997. 
Fawcett, D. W. \& Hollenberg, R. D. Changes in the acrosome of the guinea pig spermatozoa during passage through the epididymis. Z. Zellforsch. Mikrosk. Anat., 60:276-92, 1963.

Fornés, M. W. \& de Rosas, J. C. Changes in the rat sperm head during epididymal transit. Gamete Res., 24(4):453-9, 1989.

Glover, T. D. Recent progress in the study of male reproductive physiology; testis stimulation, sperm formation, transport and maturation (epididymal physiology); semen analysis, storage and A. I. In: MTP International Review of Science. Series I. Vol. 8. Reproductive Physiology. London, Butterworths, 1974. pp.221-76.

Guraya, S. S. Biology of spermatogenesis and spermatozoa in mammals. Heidelberg, Springer-Verlag, 1987.

Hafez, E. S. E. Reproduction in Farm Animals. $5^{\text {th }}$ ed. Philadelphia, Lea and Febiger, 1987. pp.203-4.

Hamilton, D. W. The mammalian epididymis. In: Balin, H. \& Glasser, S. (Eds.). Reproductive Biology. Amsterdam, Excerpta Medica, 1972. pp.269-337.

Hanks, J. Comparative aspects of reproduction in male Hyrax and Elephant. In: Calaby, J. H. \& Tryndate-Biscoe, C. H. (Eds.). Reproduction and Evolution. Canberra, Australian Academicals Science, 1977. pp.155-64.

Hahn, J.; Foote, R. H. \& Seidel, G. E. Jr. Quality and freezability of semen from growing and aged dairy bulls. J. Dairy Sci., $52(11): 1843-8,1969$

Harayama, H. Viability and protein phosphorylation patterns of boar spermatozoa agglutinated by treatment with a cellpermeable cyclic adenosine3',5'-monophosphate analog. $J$. Androl., 24(6):831-42, 2003.

Harayama, H.; Sasaki, K. \& Miyake, M. A unique mechanism for cyclic adenosine 3',5'-monophosphate-induced increase of 32$\mathrm{kDa}$ tyrosine-phosphorylated protein in boar spermatozoa. Mol. Reprod. Dev., 69(2):194-204, 2004.

Hinrichsen, M. J. \& Blaquier, J. A. Evidence supporting the existence of sperm maturation in the human epididymis. $J$. Reprod. Fertil., 60(2):291-4, 1980.

Holt, W. V. Surface-bound sialic acid on ram and bull spermatozoa: deposition during epididymal transit and stability during washing. Biol. Reprod., 23(4):847-57, 1980.

Jones, R. C. Fertility and infertility in mammals in relation to sperm structure. In: Duckett, J. G. \& Racey, P. A. (Eds.). The biology of the male gamete. London, Academic Press, 1975. pp.34365 .

Jones, R. C. Studies of the structure of the head of boar spermatozoa from the epididymis. J. Reprod. Fertil. Suppl., 13:Suppl. 13:5164, 1971
Jones, R. C.; Rowlands, I. W. \& Skinner, J. D. Spermatozoa in the genital ducts of the African elephant, Loxodonta africana. $J$. Reprod. Fertil., 41(1):189-92, 1974.

Katz, D. F.; Drobnis, E. Z. \& Overstreet, J. W. Factors regulating mammalian sperm migration through the female reproductive tract and oocyte vestments. Gamete Res., 22(4):443-69, 1989.

Lavon, U.; Volcani, R.; Amir, D. \& Danon, D. The specific gravity of bull spermatozoa and seminal plasma. J. Reprod. Fertil., 11(3):447-9, 1966.

Lindhal, P. E. \& Kihlström, J. E. Alterations in specific gravity during the ripening of bull spermatozoa. J. Dairy Sci. 35(5):393-402, 1952.

López, M. L.; Olea, N. \& Retamal, C. A. Post-testicular changes in the density and distribution of intramembrane particles of stallion sperm surface domains. Anim. Reprod. Sci., 100(12):204-10, 2007

Melrose, D. R. Assessment of semen quality. In: Maule, J. P. (Ed.). The semen of animals and artificial insemination. Franham Royal, Commonwealth Agricultural Baureaux, 1962. p.30.

O'Conner, J. J. Dollars Veterinary Surgery. $4^{\text {th }}$ ed. Delhi, CBS Publishers and Distributors, 1980

Olson, G. E.; Winfrey, V. P. \& Nagdas, S. K. Structural modification of the hamster sperm acrosome during posttesticular development in the epididymis. Microsc. Res. Tech., 61(1):4655,2003

Ostermeier, G. C.; Sargeant, G. A.; Yandell, B. S.; Evenson, D. P. \& Parrish, J. J. Relationship of bull fertility to sperm nuclear shape. J. Androl., 22(4):595-603, 2001.

Pangawkar, G. R. \& Mittal, V.P. Buffalo bull semen: Morphology, biochemistry, physiology and methodology. In: Sidhu, K. S. \& Guraya, S. S. (Eds.). Buffalo bull semen: Morphology, biochemistry, physiology and methodology. Ludhiana, USG Publishers and Distributors, 1978. p.26.

Pant, K. P. \& Mukherjee, D. P. Breed differences in the characteristics of buffalo spermatozoa. Indian J. Dairy Sci., 26:183-7, 1973

Paüfler, S. K. \& Foote, R. H. Morphology, motility and fertility of spermatozoa recovered from different areas of ligated rabbit epididymides. J. Reprod. Fertil., 17(1):125-37, 1968.

Saacke, R. G. \& White, J. M. Semen quality tests and their relationship to fertility. Madison, Proceedings of the 4th NAAB Technical Conference on Artificial Insemination and Reproduction, 1972. pp.22-7.

Salisbury, G. W.; Vandenmark, N. L. \& Lodge, J. R. Physiology of reproduction and artificial insemination of cattle. 2 nd ed. San Francisco, W. H. Freeman Co., 1978. 
DATTA, U.; BANDOPADHYAY, S. K. \& HEMBRAM, M. L. Structural modification of the black bengal buck (Capra hircus) acrosome during post-testicular maturation of spermatozoa. Int. J. Morphol., 32(4):1502-1508, 2014

Sekoni, V. O. \& Gustafsson, B. K. Seasonal variations in the incidence of sperm morphological abnormalities in dairy bulls regularly used for artificial insemination. Br. Vet. J., 143(4):3127, 1987.

Snedecor, G. W. \& Cochran, W. G. Statistical Methods. New Delhi, Oxford and IBH Publishing Co., 1980.

World Health Organization (WHO). Laboratory manual for the examination of human semen and semen-cervical mucus interactions. Cambridge, Cambridge University Press, 1987. p.80.

Yanagimachi, R. Mammalian fertilization. In: Knobil, E. \& Neill, J. D. (Eds.). The Physiology of Reproduction. New York, Raven Press, 1994. pp.289-317.
Correspondence to:

Dr. Uttam Datta, M.V.SC, Ph.D.

Department of Veterinary Gynaecology \& Obstetrics

Faculty of Veterinary and Animal Science

West Bengal University of Animal and Fishery Sciences

37and 68, Kshudiram Bose Sarabi

Belgachi, Kolkata -700037

West Bengal

INDIA

Email: udt1955@gmail.com

Received: 17-01-2012

Accepted: 06-05-2013 